\title{
Factors affecting maize, rice and wheat yields in the Koshi River Basin, Nepal
}

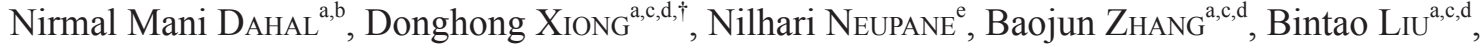 \\ Yong YUAN ${ }^{\mathrm{a}, \mathrm{b}}$, Yiping FANG ${ }^{\mathrm{f}}$, Saroj KoIRALA ${ }^{\mathrm{b}, \mathrm{f}}$ and Maan B. RoKAYA ${ }^{\mathrm{g}, \mathrm{h}}$ \\ ${ }^{\mathrm{a}}$ Key Laboratory of Mountain Hazards and Earth Surface Processes, Institute of Mountain Hazards and Environment,
Chinese Academy of Sciences, Chengdu 610041, China
${ }^{\mathrm{b}}$ University of Chinese Academy of Sciences, Beijing 100049, China
${ }^{\mathrm{c}}$ Branch of Sustainable Mountain Development, Kathmandu Center for Research and Education, CAS-TU, Kathmandu 44600, Nepal
${ }^{\mathrm{d}}$ Sino-Nepal Joint Research Centre for Geography, IMHE-TU-YNU, Kathmandu 44600, Nepal
${ }^{\mathrm{e}}$ Consultant, International Centre for Integrated Mountain Development (ICIMOD), Lalitpur, GPO 3226, Nepal
${ }^{\mathrm{f}}$ Institute of Mountain Hazards and Environment, Chinese Academy of Sciences, Chengdu 610041, China
${ }_{\mathrm{g}}^{\mathrm{g}}$ Institute of Botany, Czech Academy of Sciences, Zámek 1, 252 43 Prühonice, Czech Republic
${ }^{\mathrm{h}}$ Department of Biodiversity Research, Global Change Research Centre, Czech Academy of Sciences,
Bělidla 4a, 603 00 Brno, Czech Republic
}

\begin{abstract}
Crop yield is mainly affected by climatic factors such as temperature and precipitation. Besides these factors, improved seeds, irrigation access, and fertilizers also affect yield. In the present study, we collected crop yield data for major crops such as maize, rice, and wheat from the Koshi River Basin, Nepal. We investigated the yield trends over 30 years (1987-2016) and related the yields with climatic factors (temperature and precipitation). We also investigated the trends in the use of improved seeds, irrigation access, and fertilizer use in our study area. Results showed that there was an increase in yield of maize, rice, and wheat over 30-year period. Maize yield slightly increased with increasing average temperature. Rice yields significantly decreased with increasing temperature and precipitation, whereas wheat yield increased with increasing the diurnal temperature range. The present study suggests that future yields of maize, rice, and wheat will be affected by the increasing temperature than precipitation in the Koshi River Basin, Nepal.
\end{abstract}

Key words: Agriculture products, GLMM, Precipitation, Temperature, Yield variation

\section{Introduction}

Climate change is a key driver of agricultural production, as it affects precipitation and temperature patterns (Pachauri et al., 2008). The extreme events caused by climate change have been studied on a global scale (Alexander et al., 2006). The impact is severe for the rural livelihoods that are engaged in subsistence agriculture because of increasing water stress, diseases, and other climate induced water hazards and extremities such as drought (Paudel Khatiwada et al., 2017).

The Intergovernmental Panel for Climate Change (IPCC) reported that the average temperature increased between $0.15^{\circ} \mathrm{C}$ to $0.30^{\circ} \mathrm{C}$ per decade for the 1990 to 2005 period. It was $0.75^{\circ} \mathrm{C}$ to $0.99^{\circ} \mathrm{C}$ for $2006-2015$, and it has been estimated to be $0.8^{\circ} \mathrm{C}$ to $1.2^{\circ} \mathrm{C}$ for the $2030-2052$ period (IPCC, 2018). There is a $66 \%$ to $90 \%$ chance that the Asian monsoon precipitation will vary with increasing greenhouse gases concentration in the atmosphere. This chance of intense precipitation is projected

Received; April 5, 2020

Accepted; March 4, 2021

†Corresponding author: dhxiong@imde.ac.cn

DOI: 10.2480/agrmet.D-20-00019

(C) Author (s) 2021.

This is an open access article under the CC BY 4.0 license. to increase in the $21^{\text {st }}$ century (Folland, 2001; IPCC, 2007). A significant increase in the number of annual hot days and warm nights and a decrease in the number of rainy days were observed in the South East Asia and South Pacific region (Manton et al., 2001). Over $70 \%$ of the region experienced fewer wintry nights annually, and a significantly increased amount of precipitation.

Nepal is a topographically diverse country; mountains cover $35 \%$, hills cover $42 \%$, and flat lowlands (commonly called "Terai" in Nepali language) cover $23 \%$ of its total area. Over $65 \%$ of Nepal's population depends on agricultural activities for livelihood, which contributes to about $32 \%$ of its national gross domestic product (Ministry of Agricultural Development, 2015). Different varieties of crops are grown in Nepal. Rice, wheat, and maize are the most common and important crop species. Rice covers $45 \%$, wheat covers $18 \%$, and maize covers $20 \%$ of the total cultivated area in Nepal (Gautam, 2008; Malla, 2008). Cropping patterns vary according to the agricultural zones, from high mountains to the low Terai. Rice can be cultivated once a year from $1000 \mathrm{~m}$ to $2200 \mathrm{~m}$ above sea level and twice a year below $1000 \mathrm{~m}$ (Bhatt et al., 2014). Similarly, maize can be grown up to $2500 \mathrm{~m}$ and wheat up to $3000 \mathrm{~m}$ (Haffner, 1984; Bhatt et al., 2014). Rice production twice a year in places such as Terai and some parts of a hilly region, where there are proper irrigation facilities.

Few studies in Nepal showed that there is an erratic pattern of fewer rainy days with a high intensity of precipitation with 
no effect on the total amount of annual precipitation (Shrestha et al., 2000; Baidya and Karmacharya, 2007) causing prolonged drought and flooding. Similarly, daytime temperatures increased by $0.06^{\circ} \mathrm{C}$ to $0.12^{\circ} \mathrm{C}$ per year (Shrestha et al., 1999). According to the Representative Concentration Pathway (RCP), there will be an increment in precipitation in Nepal from 2.1\% (2016-2045) to $7.9 \%(2036-2065)$ for RCP 4.5 scenario, and from $6.4 \%$ to $12.1 \%$ for RCP 8.5 scenario compared to the reference period from 1981 to 2010 . Similarly, the temperature will increase by $0.92^{\circ} \mathrm{C}$ to $1.3^{\circ} \mathrm{C}$ for RCP 4.5 and $1.07^{\circ} \mathrm{C}$ to $1.82^{\circ} \mathrm{C}$ for RCP 8.5 in the same period (Ministry of Forests and Environment, 2019). The IPCC B2 Special Report on Emissions Scenario (B2 SRES), also mentioned that there will be an increment in mean temperature of $1.2^{\circ} \mathrm{C}$ and $3^{\circ} \mathrm{C}$, by the year 2050 and 2100 respectively (Agrawala et al., 2003).

Any climatic changes in different topographic zones may affect the cropping pattern (Pachauri et al., 2008). Increase in temperature in Terai of Nepal may harm the yield of certain crops in this region, but may be favorable for the hill and mountain zones of the country, as these zones have relatively lower temperatures under normal conditions (Malla, 2008). Crop yields also increase with improved seeds (Pandey and Velasco, 2002; Karki et al., 2010; Chhetri et al., 2012; Paudel, 2012; District Agriculture Development Office, 2016a), fertilizers (Bhatta and Neupane, 2010; Shrestha, 2010; Henderson et al., 2016), and irrigation (Bahadur et al., 2015; Dahal et al., 2015; DADO, 2016b; Paudel, 2016).

The Koshi River Basin (KRB), Nepal is home to 13.7 million people and livelihoods of people in this basin are mostly depended on agriculture (Neupane et al., 2015; Hussain et al., 2018). Rice, maize, and wheat are the major crops grown in the basin. As the basin has three major topographic regions (mountain, hill, and Terai) that include several districts, crop yield may be subjected to varying effects of change in climatic factors. Thus, a slight change in climatic factors may significantly affect the crop yields and jeopardize the overall livelihoods of the basin people. Studies focusing mainly on the variability of crop production over time because of climate change are scarce in the KRB, Nepal (Wahid et al., 2017; Hussain et al., 2018). Thus, it is important to assess the responses of crop yields with varying climatic factors, time, and topographic regions. In the present study, we collected crop yield data for maize, rice, and wheat from 16 districts in the KRB Nepal and observed the yield trends over 30 years (1987-2016) and related the yields with climatic factors (temperature and precipitation). We also observed the trends for the use of improved seeds, irrigation access, and fertilizer use.

\section{Materials and methods}

\subsection{Study area}

The KRB $\left(26^{\circ} 54^{\prime} 47^{\prime \prime} \mathrm{N}\right.$ to $25^{\circ} 24^{\prime} 43^{\prime \prime} \mathrm{N}$ latitude and $87^{\circ} 09^{\prime} 25^{\prime \prime} \mathrm{E}$ to $87^{\circ} 15^{\prime} 32^{\prime \prime} \mathrm{E}$ longitude) is a trans-boundary river system of a total $87,311 \mathrm{~km}^{2}$ covering five counties in China $(33 \%$ of its total area), 27 districts in Nepal (45\%), and 16 districts in India (22\%) (Bharati et al., 2019). In Nepal, the basin covers three distinct regions: mountains, hills, and Terai (from north to south). The Terai is at less than 300 meters above sea level ( $\mathrm{m}$ asl); it covers the northern part of the Indo-Gangetic plain and goes to the south of the Siwalik hills. The hills are at 300-2000 m asl, north of Siwalik to the south of the high mountains; the mountainous region is above $2000 \mathrm{~m}$ asl, from the north of the high mountains to the south of the Himalayas (Norbu, 2004). The major seasons are pre-monsoon (March to May), monsoon (June to September), post-monsoon (October to November), and winter (December to February) (Shrestha et al., 2000). The monsoon season is influenced by the easterly wind; it causes an enormous amount of precipitation (about $80 \%$ of the annual total precipitation) and supports the production of major summer crops such as rice and maize. The westerly wind causes the winter precipitation and the occasional precipitation in the pre-monsoon season (with hailstorms and thunderstorms). This wind contributes the remaining $20 \%$ of the total precipitation. Out of 27 districts, we purposefully selected 16 districts which are in different topographic zones (mountain, hill, and Terai) in the Koshi basin Fig. 1). We used the secondary data of the respective districts available for the period from 1987 to 2016 (Fig. 1, Appendix 1).

\subsection{Agricultural data}

Maize, rice, and wheat yield data at the district level were collected from the Ministry of Agriculture and Livestock Development, Government of Nepal from 1987 to 2016. The growing season for maize, rice, and wheat crops were noted down by visiting different places in the KRB Nepal, and from secondary literature (Paudyal et al., 2001; Nayava et al., 2009; Ghimire et al., 2012). The data were categorized according to three regions: Terai, hill, and mountain.

\subsection{Climate data}

Precipitation and the temperature are widely used climate variables to study the effects on crop yield (Peng et al., 2004). We collected minimum temperature $\left(T_{\min }\right)$, maximum temperature $\left(T_{\max }\right)$, and total precipitation for the districts of the study area. Altogether 23 meteorological stations with complete climate data from 16 districts were considered ensuring that we had the required 30 years data needed to observe the climate impact as suggested by the World Meteorological Organization (IPCC-TGICA, 2007). Station-wise monthly climate data for each year were collected from the Department of Hydrology and Meteorology (DHM), Government of Nepal (Marahatta et al., 2009; DHM, 2015, 2017). We collected the monthly climate data from June to November for rice, March to August for maize and from November (previous year) to May (next year) for wheat of mountain, hills, and Terai regions (Shrestha et al., 2000; Maharjan and Joshi, 2013). The detail data for each station are shown in Appendix 1.

\subsection{Non-climatic data}

Four types of non-climatic data were collected from the Ministry of Agriculture and Livestock Development, Government of Nepal available for the different period. They were (i) sales of improved seeds of rice, wheat, and maize (1994-2017) (ii) chemical fertilizer consumption in Nepal (1992-2016), (iii) chemical fertilizers sale under subsidy program (2009-2016), and (iv) total irrigated land in Nepal (2004-2017). 


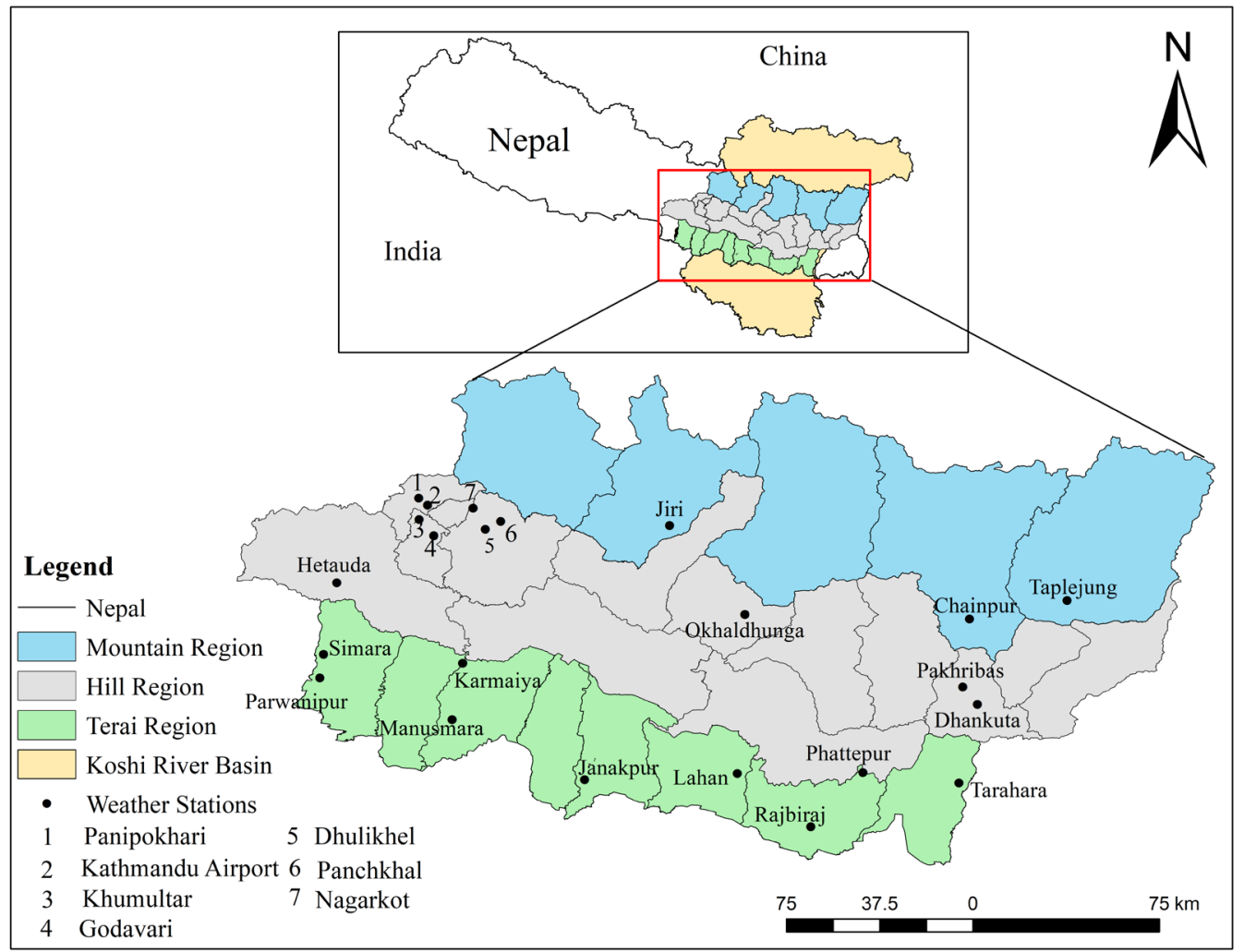

Fig. 1. Map of the study area showing districts and meteorological stations.

These data were only available at the country level at different time scales. Besides these non-climatic factors, we also observed the global carbon-dioxide $\left(\mathrm{CO}_{2}\right)$ concentration impact on crop yield. Because of the lack of availability of disaggregated data at the national and regional levels, we used global data as a proxy (Dlugokencky and Tans, 2019). The data was accessed from the two webpages (www.esrl.noaa.gov/gmd/ccgg/trends/ and https://datahub.io/core/co2-ppm\#readme).

\subsection{Data analysis}

\subsubsection{Relationship between crop yield, region, year, and} climatic factors

To observe the relationship between climatic factors and crop yield, we used the seasonal average temperature $\left(T_{\text {avg }}\right.$ in $\left.{ }^{\circ} \mathrm{C}\right)$ and diurnal temperature range (DTR in ${ }^{\circ} \mathrm{C}$ ). The $T_{\text {avg }}$ is derived as the average of minimum and maximum temperatures, and DTR is derived as the difference between the maximum and minimum temperatures for a day.

First, we used Spearman rank correlation in R 4.0.0 (R Core Team, 2020) to determine the relationships among different environmental variables (minimum temperature, maximum

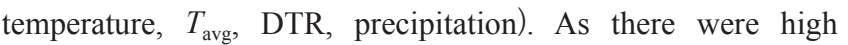
correlations $\left(\mathrm{R}^{2}>0.94\right)$ between $T_{\min }, T_{\max }$, and $T_{\text {avg }}$, we excluded $T_{\min }$ and $T_{\max }$ and only used $T_{\text {avg. }}$.

We tested the effect of different region, year, DTR, $T_{\text {avg, }}$ precipitation, and their interactions (year $\times$ region, year $\times$ DTR, year $\times T_{\text {avg }}$, and year $\times$ precipitation) on the yield of maize, rice, and wheat maize by using the generalized linear mixed effect model (GLMM). In the model, we considered the yield as a dependent variable and region, year, precipitation, $T_{\text {avg, }}$ DTR, and interactions (year $\times$ region, year $\times$ DTR, year $\times T_{\text {avg }}$, and year $\times$ precipitation) as independent variables. The interactions of region $\times$ precipitation, region $\times T_{\text {avg }}$, and region $\times$ DTR in most of the cases were insignificant. Thus, we did not consider the interactions of region and climatic factors in our analysis. However, region, as a separate variable, was kept as co-variate in the model. In the tests, we used districts as a random variable. Tests were carried out by using the lme4 package implemented in R 4.0.0 (R Core Team, 2020). In the tests, as data were right-skewed, we used gamma distribution with log link functions. To calculate the p-value, we used the drop1 function implemented in $\mathrm{R}$ and then again used the Chi-square test (R Core Team, 2020). All the figures were drawn by using Origin (Pro), version 2019b (Origin Lab Corporation, Northampton, MA, USA).

\subsubsection{Trends of non-climatic data}

The trends of different sales of improved seeds of maize, rice, and wheat yield (1994-2017), chemical fertilizer consumption in Nepal (1992-2016), chemical fertilizers sale under subsidy program (2009-2016), and total irrigated land in Nepal (2004-2017) were estimated by using the non-parametric Mann-Kendall (MK) test and Sen slope method (Mann, 1945; Kendall, 1975). The results obtained from the MK test and Sen slope was used to reflect the relationship between maize, rice, and wheat yield.

\section{Results}

\subsection{Crop plantation seasons and yield}

Maize is sown during March and harvested in August. Rice is transplanted during June and harvested in November. After the rice is harvested; wheat is sown in November and is harvested in 
May. Thus, wheat is a winter (December-February) crop, maize is a pre-monsoon (March-May) crop, and rice is a monsoon (June-September) crop in the Koshi River Basin, Nepal.

The total average annual yield of maize was $2262 \pm 656.9 \mathrm{~kg} / \mathrm{ha}$, rice was $2938 \pm 1163.4 \mathrm{~kg} / \mathrm{ha}$, and wheat was $1927 \pm 560.3 \mathrm{~kg} / \mathrm{ha}$. The maximum amount harvested for maize was $6400 \mathrm{~kg} / \mathrm{ha}$ in 2014, and the minimum amount harvested was $900 \mathrm{~kg} / \mathrm{ha}$ in 2002. The maximum amount harvested for rice was $6600 \mathrm{~kg} / \mathrm{ha}$ in 1991 , and the minimum amount harvested was $1170 \mathrm{~kg} / \mathrm{ha}$ in 1999 . The maximum amount harvested for wheat was $3670 \mathrm{~kg} / \mathrm{ha}$ in 2013 , and the minimum amount harvested was $899 \mathrm{~kg} / \mathrm{ha}$ in 1988 .

\subsection{Relationship between crop yield, region, and climatic factors}

Yield of all crops (maize, rice, and wheat) did not vary according to the regions (Terai, hill, and mountain) but significantly increased from 1987 to 2016 (Fig. 2, Table 1, Appendix 2). Maize yield slightly increased with increasing average temperature (Fig. 3a, Table 1). There was a significant effect of interactions of year $\times$ DTR and year $\times$ precipitation on maize yield (Table 1). Rice yields significantly decreased with increasing precipitation (Fig. 3b, Table 1) and average temperature (Fig. 3c, Table 1). There was a significant effect of interactions of year $\times$ region, year $\times$ DTR, and year $\times$ precipitation on rice yield (Table 1). Wheat yields slightly increased with increasing value of the DTR (Fig. 3d, Table 1). There was a significant effect of interactions of year $\times$ region, year $\times$ DTR, year $\times T_{\text {avg }}$, and year $\times$ precipitation on wheat yield (Table 1).

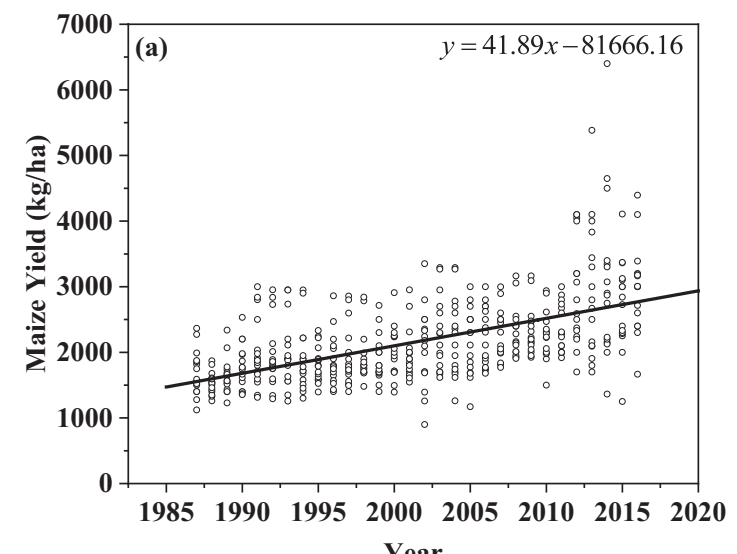

Year

\subsection{Trends of non-climatic factors}

The details of the trend of non-climatic factors in Nepal are given in Table 2. Results showed that from 1994 to 2017, the sale of improved rice and wheat seeds had a significant increasing trend of 110.47 metric tons (MT) and 114.43 MT per year respectively in Nepal. The consumption trend of fertilizer increased after 2009 when the government started a subsidy program in fertilizers. After the subsidy program, the fertilizer sale had a significant increasing trend of 42,828 MT per year. Similarly, the area of irrigated land also significantly increased from 2004 to 2016 by 37445 ha per year.

\section{Discussion}

Increasing crop yield is important for food security in a growing population in the world (Kang et al., 2009). However, different climatic factors negatively and/or positively affect production, and thus it is important to observe their effects on sustainable agriculture production (Siwar et al., 2009). The present study has shown that there was a variation in the yield of three major crops (maize, rice, and wheat) over the 30-year period, and has analyzed how different climatic factors affect these three major crop yields.

Cultivation of different crops in particular months was carried out according to the adaptability of crop type. Maize and wheat require less water and temperature, so they were cultivated during pre-monsoon and winter. Rice requires abundant water supply and high temperature, and is intensively cultivated during the warm growing seasons. This shows that different regions in

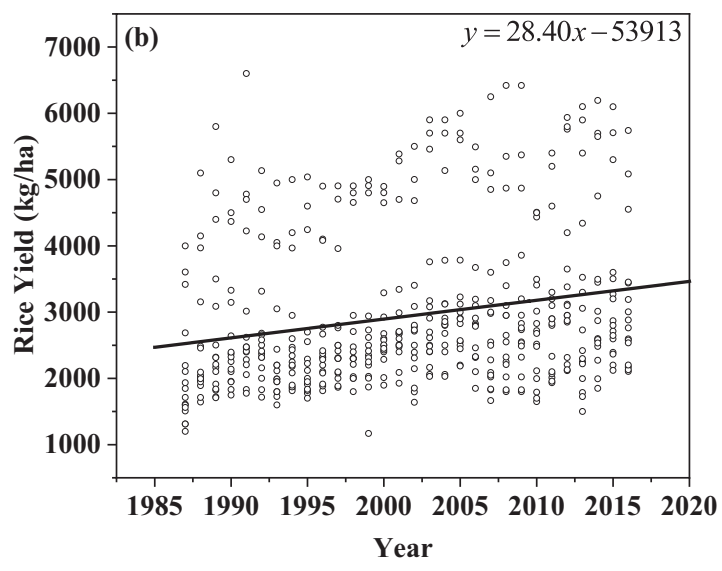

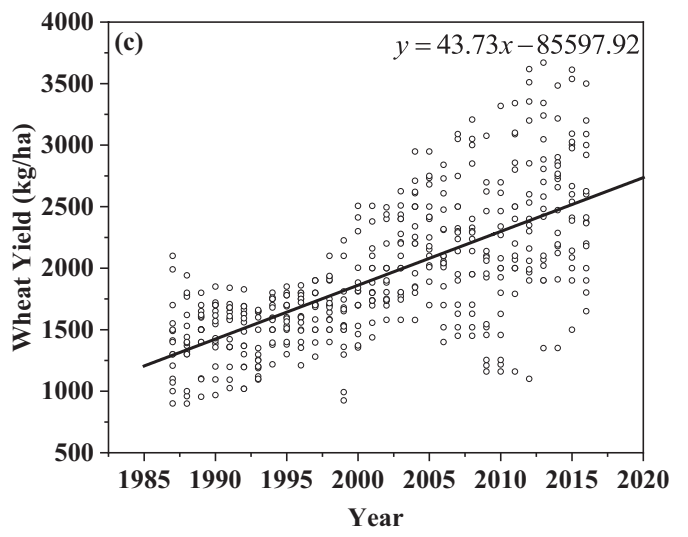

Fig. 2. Relationships between (a) maize yield and year, (b) rice yield and year and (c) wheat yield and year in the Koshi River Basin, Nepal. 
Table 1. Summarized results of the generalized linear mixed effect model (GLMM) testing the effects of region, year, DTR, $T_{\text {avg }}$ and precipitation on the yield of rice, wheat and maize in Koshi River Basin, Nepal from 1987 to 2016. The p-values marked in bold are significant.

\begin{tabular}{lccccccc}
\hline & \multicolumn{4}{c}{ Maize } & \multicolumn{2}{c}{ Rice } & \multicolumn{2}{c}{ Wheat } \\
\cline { 2 - 8 } Factors & $\mathbf{d f}$ & p-value & $\mathbf{R}^{\mathbf{2}}$ & p-value & $\mathbf{R}^{\mathbf{2}}$ & p-value & $\mathbf{R}^{\mathbf{2}}$ \\
\hline Region & $\mathbf{2}$ & 0.394 & - & 0.050 & - & 0.157 & - \\
Year & 29 & $<\mathbf{0 . 0 0 1}$ & 0.784 & $<\mathbf{0 . 0 0 1}$ & 0.647 & $<\mathbf{0 . 0 0 1}$ & 0.862 \\
Diurnal temperature range (DTR) & 1 & 1.000 & - & 0.755 & - & $\mathbf{0 . 0 2 8}$ & 0.003 \\
Average temperature $\left(T_{\text {avg }}\right)$ & 1 & $\mathbf{0 . 0 4 6}$ & 0.005 & $<\mathbf{0 . 0 0 1}$ & 0.042 & 0.423 & - \\
Total precipitation & 1 & 0.580 & - & $\mathbf{0 . 0 1 1}$ & 0.006 & 0.545 & - \\
Year $\times$ region & 58 & 0.260 & - & $<\mathbf{0 . 0 0 1}$ & 0.125 & $<\mathbf{0 . 0 0 1}$ & 0.058 \\
Year $\times$ DTR & 29 & $<\mathbf{0 . 0 0 1}$ & 0.049 & $\mathbf{0 . 0 0 4}$ & 0.039 & $<\mathbf{0 . 0 0 1}$ & 0.020 \\
Year $\times T_{\text {avg }}$ & 29 & 0.644 & - & 0.170 & - & $<\mathbf{0 . 0 0 1}$ & 0.022 \\
Year $\times$ precipitation & 29 & $\mathbf{0 . 0 0 3}$ & 0.046 & $\mathbf{0 . 0 0 9}$ & 0.041 & $\mathbf{0 . 0 3 9}$ & 0.014 \\
\hline
\end{tabular}
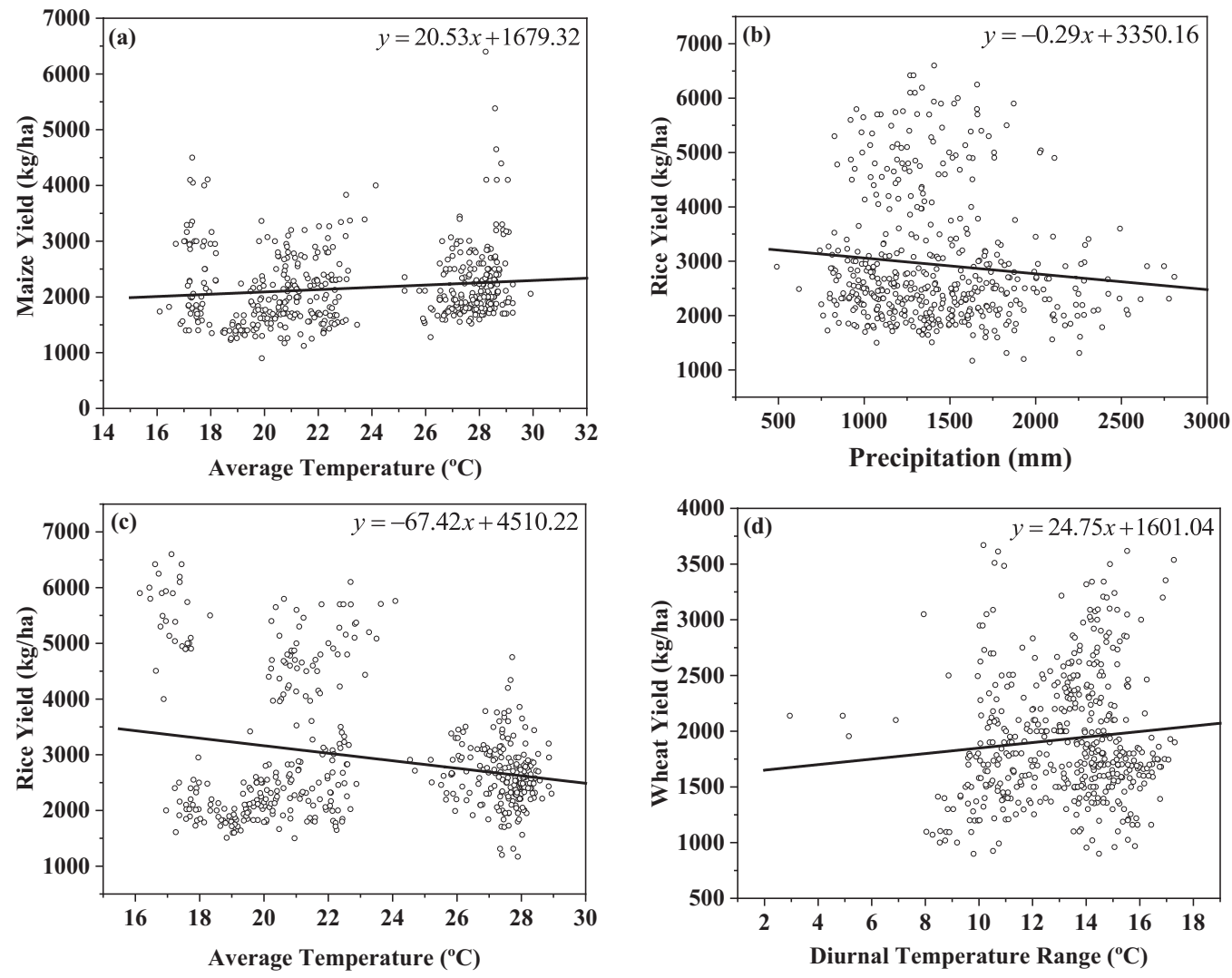

Fig. 3. Relationships between (a) maize yield and average temperature, (b) rice yield and precipitation, (c) rice yield and precipitation and (d) wheat yield and diurnal temperature range.

Table 2. The trend of the non-climate variables affecting crop yield over different periods in Nepal. The p-values marked in bold are significant.

\begin{tabular}{lcc}
\hline Non-Climatic factors & \multicolumn{2}{c}{ Statistics } \\
& p-value & Slope \\
\hline Improved rice seeds & $<\mathbf{0 . 0 0 1}$ & $110.47^{\mathrm{a}}$ \\
Improved wheat seeds & $<\mathbf{0 . 0 0 1}$ & $114.43^{\mathrm{a}}$ \\
Improved maize seeds & 0.939 & $-0.1823^{\mathrm{a}}$ \\
Chemical Fertilizers consumption & 0.309 & $0.78^{\mathrm{b}}$ \\
Chemical fertilizer sale after subsidy program & $<\mathbf{0 . 0 0 1}$ & $42828^{\mathrm{a}}$ \\
Total irrigated land & $<\mathbf{0 . 0 0 1}$ & $37445^{\mathrm{c}}$ \\
\hline
\end{tabular}

$\mathrm{a}=$ MT per year; $\mathrm{b}=\mathrm{kg}$ per ha per year; $\mathrm{c}=$ ha per year 
the world have their own unique crop production cycles, which require certain farming techniques to achieve optimum yield (Paudyal et al., 2001; Nayava et al., 2009; Ghimire et al., 2012). The quantity of different crop yield in the same place is not uniform and also varies over time or from year to year because of variations in environmental factors (Wahid et al., 2017; Hussain et al., 2018), soil conditions and use of fertilizers (Neenu et al., 2013), types of seed used (Pandey and Velasco, 2002; Karki et al., 2010; Chhetri et al., 2012; Paudel, 2012; DADO, 2016a) and also occurrence of natural calamities.

Yield of all crops did not vary according to the regions in our study. This is obvious as the region lies in the east Nepal and receives relatively more precipitation that is enough as required by different crops compared to the center and the west Nepal (Marahatta et al., 2009; DHM, 2015, 2017). However, the results showed a significant effect for the interaction between year and regions for rice and wheat, suggesting that the yields of these two crops were different among regions depending on the year.

Our finding of an increase in yield of maize, rice, and wheat from 1987 to 2016 is consistent with other studies from Nepal (Pant, 2012; Shrestha et al., 2012; Maharjan and Joshi, 2013; Aryal et al., 2016; Dhakal et al., 2016; Poudel and Shaw, 2016). The increase in yield is might be due to the use of improved agricultural techniques (DADO, 2016a, 2016b), better seeds (CDD and ASoN, 2017), improved cultivars (Pandey and Velasco, 2002; Karki et al., 2010; Chhetri et al., 2012; Paudel, 2012; DADO, 2016a), use of irrigation (Bahadur et al., 2015; Dahal et al., 2015; DADO, 2016b; Paudel, 2016), and use of fertilizers (Bhatta and Neupane, 2010; Shrestha, 2010; Neupane, 2011; Neenu et al., 2013; Henderson et al., 2016). There is also use of improved crop varieties, input levels, timing of cropping, and managing water sources for better yield elsewhere in the world, including Nepal (Neupane, 2011; Lobell and Gourdji, 2012; Chen et al., 2015; Ara et al., 2017).

The finding of a slight increase in maize yield with increasing temperature in our results is consistent with other studies (Chen et al., 2015; Liu et al., 2017) but different to Zhang and Huang (2012) who mentioned that the warmer temperature and less precipitation during the maize growing season have a negative impact the yield. High temperature has positive effects on the seedling growth and the maturity phases of maize crop resulting into a better maize yield (Yin et al., 2016).

In our study, rice yield significantly decreased with increasing temperature and precipitation showing that increased temperature might affect the physiological development of rice inhibiting yield. Increasing temperatures reduce the soil moisture, creating water stress on rice (Fukai and Cooper, 1995). A study by Boote et al. (2005) on rice revealed that the yield decreases by $10 \%$ above the $T_{\text {avg }}$ of $25^{\circ} \mathrm{C}$ up to $36^{\circ} \mathrm{C}$ after which the plant cannot form the grain. Similarly, in a changing climate, Tashiro and Wardlaw (1989) revealed the decline of the grain mass by $4.4 \%$ in $1^{\circ} \mathrm{C}$ increase in temperature above $25^{\circ} \mathrm{C}$ and Baker and Allen (1993) mentioned the possibility of yield loss by 9.6 to $10 \%$ in every $1^{\circ} \mathrm{C}$ increase in temperature above $25^{\circ} \mathrm{C}$. Ara et al. (2017) showed the negative impact of temperature in the yield of two rice varieties (Aus and Aman) in Bangladesh. Likewise, Oerke (2006) also mentioned that the high temperatures and high precipitation often result in the growth of pests and diseases, especially in the tropical and sub-tropical areas that might affect the yield of various crops. Chakraborty et al. (2000) discussed the rice blast disease that can affect the rice growth and yield because of increasing temperature, especially in the Asian rice-growing region. High amount of rain also causes flooding, landslides and wash the top soils leading to degradation of land and thus result in a decrease of crop yield including rice (Mohammadi et al., 2020).

Wheat yields slightly increased with increasing value of the DTR. This finding resembles with other studies in Nepal showing the increment in the DTR is because of a higher rate of increasing maximum temperature than the minimum (Marahatta et al., 2009; DHM, 2015; DHM, 2017). DTR increment results from increase maximum temperature that shows overall positive correlation of wheat yield in north China (Zhang et al., 2013). We have considered November to May as a wheat-growing season, which includes winter and pre-monsoon season in Nepal. Winter includes the seedling, tillering, and plant elongation stage and later season includes the spike formation, flowering, ripening and harvesting stage (DADO, 2016a). During the later stage, the temperature is comparatively higher than the earlier stage and hence the yield gets benefited, especially when the grain formation or crop development rates are more sensitive to minimum temperature than the maximum (Wilkens and Singh, 2003; Tao et al., 2008). The increased DTR during the growing season also shows the warming days and cooling night, which is beneficial for crop growth as the photosynthetic rate increase during the day and respiration rate reduce during the night (Leopold and Kriedemann, 1975; Ryan, 1991; Chen et al., 2015). A study by Chakrabarti et al. (2011) in India found that the low temperatures during the reproductive stage of wheat cause yield reduction because of pollen sterility. Their study showed an increasing temperature enhanced the pollen germination it results into a high wheat yield.

There was a significant effect of interactions of year $\times$ DTR on maize, rice and wheat yields, meaning that the DTR is variable in different years and the yield partly depends on the variation of the DTR. Thus, DTR is probably the most important factor in the life cycle of maize, rice, and wheat. Similarly, the significant effect of interactions of year $\times$ regions for rice and wheat yield might be due to use of different farming techniques, use of a different rotation of crops, change in cultivation patterns or even because of variations in the occurrence of natural calamities in different regions (Neupane, 2011; Lobell and Gourdji, 2012; Chen et al., 2015; Ara et al., 2017). There were also variations in precipitation and temperature during different years (Agrawala et al., 2003) and the yield of rice and wheat depend on favorable precipitation or temperature in a year thus there was a significant effect of interactions of year $\times$ precipitation on rice yield and also a significant effect of interactions of year $\times$ precipitation and year $\times T_{\text {avg }}$ on wheat yield.

The variation in crop yield of maize, rice, and wheat is also partly because of their existing plant physiology. Considering the plant physiology of selected crops in the study area, rice and wheat are C3 plants and maize is a C4 plant. During photosynthesis, $\mathrm{C} 3$ plants initially convert carbon dioxide into 
3-carbon compounds and $\mathrm{C} 4$ plants convert it into four-carbon compounds (Ehleringer and Cerling, 2002). Thus, the C3 and C4 plants respond differently to the changing temperature during photosynthesis and vary the amounts of carbon dioxide in the atmosphere and water availability. $\mathrm{C} 4$ plants are more productive photosynthetically compared with $\mathrm{C} 3$ plants and can cope with higher temperatures and low water availability (Ehleringer and Cerling, 2002). Besides this, crop yield is also partly depended on its existing genetic conditions and therefore, maize, rice, and wheat differ in their genetic conditions resulting in their yields (Lobell and Gourdji, 2012).

Amthor (1998) discussed that, in the past 100 years, crop yield in most of the countries increase along with the increased in atmospheric carbon dioxide. From 1987 to 2016, the atmospheric $\mathrm{CO}_{2}$ concentrations measured at Mauna Loa in Hawaii, the United States of America increased by 55 ppm (Dlugokencky and Tans, 2019). A study by Ainsworth et al. (2008) on the effects of $\mathrm{CO}_{2}$ concentration in $\mathrm{C} 3$ crops (rice, soybean and wheat) showed about $0.065 \%$ yield increase per ppm. Based on this; Lobell et al. (2011) explained about a 3\% increase in rice and wheat yield from 1980 to 2008, when the $\mathrm{CO}_{2}$ concentration increased by $47 \mathrm{ppm}$. Thus, in our study from 1987 to 2016, the increased $\mathrm{CO}_{2}$ concentration of $55 \mathrm{ppm}$ would have contributed about $3.5 \%$ to the increase in the $\mathrm{C} 3$ crop yield (rice and wheat). For the maize, as discussed earlier, it has a C4 photosynthetic pathway which, unlike $\mathrm{C} 3$ plants, has no stimulation of photosynthesis to the increased $\mathrm{CO}_{2}$ concentration (Malla, 2008; Leakey, 2009).

\section{Conclusions}

Our study assessed the maize, rice, and wheat crop yield trends over 30 years (1987-2016) in the Koshi River Basin, Nepal. It was found that rice was produced in the highest amount, followed by wheat and maize. All crop types yield steadily increased in the recent years. There was a negative impact of increasing temperature and precipitation for rice, but a positive impact of increasing DTR for wheat. The effects of interactions of year and factors such as DTR, precipitation and $T_{\text {avg }}$ on different crops were variable. It is concluded that crop production is variable over the study period (1987-2016) and are affected by different climatic factors. It is necessary to observe how crop production is affected to ensure food security for increasing human population. Although this study covers only three crop types in the Koshi River Basin in Nepal, it is expected to serve as a model for further studies.

\section{Acknowledgments}

The study was funded by the NSFC-ICIMOD Joint Research Project (Grant No. 41661144038) and the CAS Overseas Institutions Platform Project (Grant No. 131C11KYSB20200033). The authors would like to thank the Department of Hydrology and Meteorology and Ministry of Agriculture and Livestock Development, Government of Nepal for providing raw data for this research work. We are thankful to Dr. Bikram Pandey, Belayneh Yigez, Belayneh Azene and Javed Hassan (Chinese Academy of Sciences) for their constructive suggestions during the revision work. Maan B. Rokaya was supported by a long-term research and development project (RVO 67985939, www.ibot.cas.cz).

\section{References}

Agrawala S, Raksakulthai V, Aalst M et al., 2003: Development and Climate Change in Nepal: Focus on Water Resources and Hydropower. Organisation for Economic Co-operation and Development. Paris, France, pp. 64.

Ainsworth EA, Leakey AD, Ort DR et al., 2008: FACE-ing the facts: inconsistencies and interdependence among field, chamber and modeling studies of elevated $\left[\mathrm{CO}_{2}\right]$ impacts on crop yield and food supply. New Phytologist 179, 5-9.

Alexander LV, Zhang X, Peterson TC et al., 2006: Global observed changes in daily climate extremes of temperature and precipitation. Journal of Geophysical Research: Atmospheres 111, 1-22.

Amthor JS, 1998: Perspective on the relative insignificance of increasing atmospheric $\mathrm{CO}_{2}$ concentration to crop yield. Field Crops Research 58, 109-127.

Ara I, Lewis M, Ostendorf B, 2017: Understanding the Spatially Variable Effects of Climate Change on Rice Yield for Three Ecotypes in Bangladesh, 1981-2010. Advances in Agriculture 2017, 1-11.

Aryal M, Regmi P, Thapa R et al., 2016: Impact of climate variables to major food crops' yield in midhills of western development region, Nepal. Journal of Agriculture and Environment 17, 65-72.

Bahadur KD, Gadal N, Neupane S et al., 2015: Maize seed marketing chains and marketing efficiency along supply chains of the hills in Nepal. International Journal of Agricultural Marketing 2, 026-033.

Baidya S, Karmacharya J, 2007: Observed and Future Climate Change in Nepal. National Workshop on Climate Change and Human Health: Potential Impact, Vulnerability and Adaptation in Nepal. (ed. by Meghnath D). December 19-21 2007, Kathmandu, Nepal, pp. 19-21.

Baker J, Allen L, 1993: Contrasting crop species responses to $\mathrm{CO}_{2}$ and temperature: rice, soybean and citrus. Vegetatio 104, 239-260.

Bharati L, Bhattarai U, Khadka A et al., 2019: From the Mountains to the Plains: Impact of Climate Change on Water Resources in the Koshi River Basin. International Water Management Institute (IWMI). Colombo, SriLanka, pp. 49.

Bhatt D, Maskey S, Babel MS et al., 2014: Climate trends and impacts on crop production in the Koshi River basin of Nepal. Regional Environment Change 14, 1291-1301.

Bhatta GD, Neupane N, 2010: Simulating farm income under the current soil management regime in the mid-hills of Nepal. Himalayan Journal of Sciences 6, 27-34.

Boote KJ, Allen LH, Prasad PV et al., 2005: Elevated temperature and $\mathrm{CO}_{2}$ impacts on pollination, reproductive growth, and yield of several globally important crops. Journal of Agricultural Meteorology 60, 469-474.

CDD, ASoN, 2017: Rice Science and Technology in Nepal. Crop Development Directorate (CDD), Agronomy Society of Nepal (ASoN), Lalitpur, pp. 1-976.

Chakrabarti B, Singh S, Nagarajan S et al., 2011: Impact of temperature on phenology and pollen sterility of wheat varieties. Australian Journal of Crop Science 5, 1039-1043.

Chakraborty S, Tiedemann A, Teng PS, 2000: Climate change: potential impact on plant diseases. Environmental pollution 108, 317-326.

Chen C, Zhou G, Pang Y, 2015: Impacts of climate change on 
maize and winter wheat yields in China from 1961 to 2010 based on provincial data. The Journal of Agricultural Science 153, 825-836.

Chhetri N, Chaudhary P, Tiwari PR et al., 2012: Institutional and technological innovation: Understanding agricultural adaptation to climate change in Nepal. Applied Geography 33, 142-150.

District Agriculture Development Office, 2016a: Wheat Seed Production Techniques Manual. Government of Nepal, Ministry of Agriculture Development, Regional Agriculture Directorate, Central Development Region, District Agriculture Development Office (DADO), Sindhupalchok, pp. 49.

District Agriculture Development Office, 2016b: Maize Farming Techniques Manual. Government of Nepal, Ministry of Agriculture Development, Regional Agriculture Directorate, Central Development Region, District Agriculture Development Office (DADO), Sindhupalchok, pp. 44.

Dahal KR, Puri RR, Joshi AK, 2015: Effect of climate change and associated factors on the production and productivity of wheat (Triticum aestivum L.) over last 25 years in the Terai region of Nepal. International Journal of Environment 4, 151-165.

Dhakal S, Sedhain G, Dhakal S, 2016: Climate change impact and adaptation practices in agriculture: A case study of Rautahat District, Nepal. Climate 4, 1-22.

DHM, 2015: Study of Climate and Climatic Variation Over Nepal. Government of Nepal, Department of Hydrology and Meteorology (DHM). Kathmandu, pp. 41.

DHM, 2017: Observed Climate Trend Analysis in the Districts and Physiographic Regions of Nepal (1971-2014). Government of Nepal, Ministry of Population and Environment, Department of Hydrology and Meteorology (DHM). Kathmandu, pp. 87.

Dlugokencky E, Tans P, 2019: Trends in Atmospheric Carbon Dioxide, Global. http://www.esrl.noaa.gov/gmd/ccgg/trends/ global.html, https://datahub.io/core/co2-ppm\#citations. Accessed 10 December 2019.

Ehleringer JR, Cerling TE, 2002: C3 and C4 photosynthesis. In Encyclopedia of Global Environmental Change (ed. by Mooney HA, Canadell JG). John Wiley \& Sons Limited, Chichester, pp. 186-190.

Folland CK, Karl TR, Christy JR et al., 2001: Observed Climate Variability and Change. In In: Climate change 2001: the scientific basis (ed. by Houghton JT, Ding Y, Griggs DJ et al.). Cambridge University Press, Cambridge, United Kingdom and New York, NY, USA, pp. 881.

Fukai S, Cooper M, 1995: Development of drought-resistant cultivars using physiomorphological traits in rice. Field Crops Research 40, 67-86.

Gautam J, 2008: Country Report on the State of the Nepal's Plant Genetic Resources for Food and Agriculture. Commission on Genetic Resources for Food and Agriculture. Kathmandu, pp. 91.

Ghimire R, Adhikari KR, Chen Z-S et al., 2012: Soil organic carbon sequestration as affected by tillage, crop residue, and nitrogen application in rice-wheat rotation system. Paddy and Water Environment 10, 95-102.

Haffner W, 1984: Natural Environment and Man in Tropical Mountain Ecosystems. In Potentials and Limits of Agricultural Production in Nepal as seen from an Ecological-Geographical Standpoint (ed. by Lauer W). F. Steiner Verlag Wiesbaden, Stuttgart, pp. 115-126.
Henderson C, Piya S, Kharel M, 2016: Market-based strategies to upscale organic fertilizer use in Nepal to achieve productivity, resilience, and the SDGs. Food Chain 6, 51-64.

Hussain A, Rasul G, Mahapatra B et al., 2018: Climate change-induced hazards and local adaptations in agriculture: a study from Koshi River Basin, Nepal. Natural Hazards, 1-19.

IPCC-TGICA, 2007: General Guidelines on the Use of Scenario Data for Climate Impact and Adaptation Assessment, Version 2. Intergovernmental Panel on Climate Change (IPCC), Task Group on Scenario Support for Impact and Climate Assessment (TGICA). Geneva, pp. 66.

IPCC, 2007: The Physical Science Basis. Contribution of Working Group I to the Fourth Assessment Report of the Intergovernmental Panel on Climate Change. Cambridge University Press. Cambridge and New York, pp. 996.

IPCC, 2018: Special Report on Global Warming of $1.5^{\circ} \mathrm{C}$. Intergovernmental Panel on Climate Change. Geneva, Switzerland, pp. 1-24.

Kang Y, Khan S, Ma X, 2009: Climate change impacts on crop yield, crop water productivity and food security-A review. Progress in Natural Science 19, 1665-1674.

Karki T, Koirala K, Bk S, 2010: Participatory variety slection of cold tolerant rice in the western hills of Nepal. Agronomy Journal of Nepal 1, 74-79.

Kendall M, 1975: Rank correlation measures Charles Griffin, London, pp. 220.

Leakey AD, 2009: Rising atmospheric carbon dioxide concentration and the future of C4 crops for food and fuel. Proceedings of Royal Society B Biological Sciences 276, 2333-2343.

Leopold A, Kriedemann P, 1975: Plant growth and development, $2 d$ ed. McGraw-Hill Book Co., New York, San Francisco, Toronto, London, pp. 466.

Liu B, Chen X, Meng Q et al., 2017: Estimating maize yield potential and yield gap with agro-climatic zones in ChinaDistinguish irrigated and rainfed conditions. Agricultural and forest meteorology 239, 108-117.

Lobell DB, Gourdji SM, 2012: The influence of climate change on global crop productivity. Plant Physiology 160, 1686-1697.

Lobell DB, Schlenker W, Costa-Roberts J, 2011: Climate trends and global crop production since 1980. Science 333, 616-620.

Maharjan KL, Joshi NP, 2013: Climate Change, Agriculture and Rural Livelihoods in Developing Countries. In Effect of Climate Variables on Yield of Major Food-Crops in Nepal: A Time-Series Analysis (ed. by Nüsser M). Springer, Tokyo, pp. 127-137.

Malla G, 2008: Climate change and its impact on Nepalese agriculture. Journal of Agriculture and Environment 9, 62-71.

Mann HB, 1945: Nonparametric Tests Against Trend. Econometrica 13, 245-259.

Manton MJ, Della-Marta PM, Haylock MR et al., 2001: Trends in extreme daily rainfall and temperature in Southeast Asia and the South Pacific: 1961-1998. International Journal of Climatology 21, 269-284.

Marahatta S, Dangol BS, Gurung GB, 2009: Temporal and Spatial Variability of Climate Change Over Nepal, 1976-2005. Practical Action Nepal Office, Kathmandu.

Ministry of Agricultural Development, 2015: Statistical Information on Nepalese Agriculture 2014/15. Government of Nepal, Ministry of Agricultural Development (MOAD), Agri-Business Promotion and Statistics Division Agri statistics 
Section, Kathmandu.

Ministry of Forests and Environment, 2019: Climate change scenarios for Nepal for National Adaptation Plan (NAP). Ministry of Forest and Environment, Nepal Government. Kathmandu, pp. 66.

Mohammadi M, Darabi H, Mirchooli F et al., 2020: Flood risk mapping and crop-water loss modeling using water footprint analysis in agricultural watershed, northern Iran. Natural Hazards, 1-19.

Nayava JL, Singh R, Bhatta MR, 2009: Impact of climate, climate change and modern technology on wheat production in Nepal: a case study at Bhairahawa. Journal of Hydrology and Meteorology 6, 1-14.

Neenu S, Biswas A, Rao AS, 2013: Impact of climatic factors on crop production-A review. Agricultural Reviews 34, 97-106.

Neupane N, 2011: Farming and Rural Systems Economics. In Political-Economy of Water Distribution in the Trans-Himalayan Region of Nepal (ed. by Doppler W, Bauer S). Margraf Publishers GmbH, Weikersheim, pp. 1-212.

Neupane N, Nibanupudi HK, Gurung MB, 2015: Interlacing of regional water policies, institutions and agreements with livelihoods and disaster vulnerabilities in the HKH region: A case study of Kosi River Basin. In Mountain Hazards and Disaster Risk Reduction (ed. by Nibanupudi H, Shaw R). Springer, Tokyo, pp. 251-270.

Norbu N, 2004: Invasion Success of Chromolaena odorata in the Terai of Nepal. Geo-Information Science, International Institute for Geo-information and Earth Observation (ITC). Enschede, pp. 41.

Oerke E-C, 2006: Crop losses to pests. Journal of agricultural science 144, 31-43.

Pachauri RK, Srivastava L, Mishra A et al., 2008: Ecosystem Services and Poverty Alleviation Study in South Asia, A Situation Analysis for India and The HinduKush Himalayan Region. New Delhi, pp. 84.

Pandey S, Velasco L, 2002: Economics of Direct Seeding in Asia: Patterns of Adoption and Research Priorities. Direct seeding: research issues and opportunities. Proceedings of the International Workshop on Direct Seeding in Asian Rice Systems: Strategic Research Issues and Opportunities. (ed. by Pandey S, Mortimer M, Wadel L et al.). 25-28 January 2000, Bangkok, Thailand, pp. 3-14.

Pant KP, 2012: Climate change and food security in Nepal. Journal of Agriculture and Environment 13, 9-19.

Paudel Khatiwada S, Deng W, Paudel B et al., 2017: Household livelihood strategies and implication for poverty reduction in rural areas of central Nepal. Sustainability 9, pp. 1-20.

Paudel MN, 2012: Adaptation mechanisms in agriculture for climate change in Nepal. Hydro Nepal: Journal of Water, Energy and Environment 11, 81-85.

Paudel MN, 2016: Consequences of climate change in agriculture and ways to cope up its effect in Nepal. Agronomy Journal of Nepal 4, 25-37.

Paudyal KR, Ransom JK, Adhikari K et al., 2001: Maize in Nepal: Production Systems, Constraints, and Priorities for Research. Nepal Agricultural Research Council, International Maize and Wheat Improvement Center, Kathmandu, pp. 48.
Peng S, Huang J, Sheehy JE et al., 2004: Rice Yields Decline with Higher Night Temperature from Global Warming. Proceedings of the National Academy Sciences of the United States of America, pp. 9971-9975.

Poudel S, Shaw R, 2016: The relationships between climate variability and crop yield in a mountainous environment: a case study in Lamjung District, Nepal. Climate 4, pp. 1-19.

$\mathrm{R}$ Core Team, 2020: $R:$ A language and environment for statistical computing. R Foundation for Statistical Computing, Vienna, Austria. https://www.R-project.org/. Accessed 24th July 2020.

Ryan MG, 1991: Effects of climate change on plant respiration. Ecological Applications 1, 157-167.

Shrestha AB, Wake CP, Dibb JE et al., 2000: Precipitation fluctuations in the Nepal Himalaya and its vicinity and relationship with some large scale climatological parameters. International Journal of Climatology 20, 317-327.

Shrestha AB, Wake CP, Mayewski PA et al., 1999: Maximum temperature trends in the Himalaya and its vicinity: an analysis based on temperature records from Nepal for the period 1971-94. Journal of Climate 12, 2775-2786.

Shrestha RK, 2010: Fertilizer policy development in Nepal. Journal of Agriculture and Environment 11, 126-137.

Shrestha SL, Maharjan KL, Joshi NP, 2012: Relationship between climate variables and yields of food crops in Nepal: Cases of Makwanpur and Ilam Districts. Journal of International Development and Cooperation 18, 37-54.

Siwar C, Alam MM, Murad MW et al., 2009: A Review of the Linkages between Climate Change, Agricultural Sustainability and Poverty in Malaysia. International Review of Business Research Papers 5, 309-321.

Tao F, Yokozawa M, Liu J et al., 2008: Climate-crop yield relationships at provincial scales in China and the impacts of recent climate trends. Climate Research 38, 83-94.

Tashiro T, Wardlaw IF, 1989: A comparison of the effect of high temperature on grain development in wheat and rice. Annals of Botany 64, 59-65.

Wahid SM, Kilroy G, Shrestha AB et al., 2017: River System Analysis and Management. In Opportunities and challenges in the Trans-boundary Koshi River Basin (ed. by Nayan S). Springer, Singapore, pp. 341-352.

Wilkens P, Singh U, 2003: A code-level analysis for temperature effects in the CERES models. Modeling temperature response in wheat and maize. (ed. by White JW). 23-25 April, 2001, El Batán, Mexico, pp 1-7.

Yin X, Jabloun M, Olesen JE et al., 2016: Effects of climatic factors, drought risk and irrigation requirement on maize yield in the Northeast Farming Region of China. The Journal of Agricultural Science 154, 1171-1189.

Zhang T, Huang Y, 2012: Impacts of climate change and inter -annual variability on cereal crops in China from 1980 to 2008. Journal of the Science of Food and Agriculture 92, 1643-1652.

Zhang X, Wang S, Sun H et al., 2013: Contribution of cultivar, fertilizer and weather to yield variation of winter wheat over three decades: A case study in the North China Plain. European Journal of Agronomy 50, 52-59. 
Appendix 1. Details of selected districts and meteorological stations in the Koshi River Basin, Nepal.

\begin{tabular}{|c|c|c|c|c|c|}
\hline District & Station Name & Latitude $\left({ }^{\circ} \mathbf{N}\right)$ & Longitude $\left({ }^{\circ} \mathbf{E}\right)$ & Elevation (m) & Station Index \\
\hline Dolakha $^{a}$ & Jiri & 27.63 & 86.23 & 1877 & 1103 \\
\hline Sankhuwasabha ${ }^{a}$ & Chainpur & 27.29 & 87.31 & 1277 & 1303 \\
\hline Taplejung $^{\mathrm{a}}$ & Taplejung & 27.35 & 87.67 & 1744 & 1405 \\
\hline \multirow[t]{2}{*}{ Kathmandu ${ }^{\mathrm{b}}$} & Panipokhari & 27.72 & 85.32 & 1329 & 1039 \\
\hline & Kathmandu Airport & 27.70 & 85.35 & 1337 & 1030 \\
\hline \multirow[t]{2}{*}{ Lalitpur $^{\mathrm{b}}$} & Khumaltar & 27.65 & 85.32 & 1334 & 1029 \\
\hline & Godavari & 27.59 & 85.37 & 1527 & 1022 \\
\hline Makwanpur $^{\mathrm{b}}$ & Hetauda & 27.42 & 85.02 & 452 & 906 \\
\hline Bhaktapur $^{\mathrm{b}}$ & Nagarkot & 27.69 & 85.52 & 2147 & 1043 \\
\hline \multirow[t]{2}{*}{ Kavre $^{\mathrm{b}}$} & Dhulikhel & 27.61 & 85.56 & 1543 & 1024 \\
\hline & Panchkhal & 27.64 & 85.62 & 857 & 1036 \\
\hline Okhaldhunga $^{\mathrm{b}}$ & Okhaldhunga & 27.30 & 86.50 & 1731 & 1206 \\
\hline \multirow[t]{2}{*}{ Dhankuta $^{\mathrm{b}}$} & Pakhribas & 27.04 & 87.29 & 1720 & 1304 \\
\hline & Dhankuta & 26.98 & 87.34 & 1192 & 1307 \\
\hline \multirow[t]{2}{*}{ Bara $^{c}$} & Simara & 27.16 & 84.98 & 137 & 909 \\
\hline & Parwanipur & 27.06 & 84.96 & 87 & 911 \\
\hline \multirow[t]{2}{*}{ Sarlahi $^{\mathrm{c}}$} & Karmaiya & 27.13 & 85.48 & 139 & 1121 \\
\hline & Manusmara & 26.92 & 85.44 & 90 & 1118 \\
\hline Dhanusa $^{c}$ & Janakpur & 26.71 & 85.92 & 76 & 1111 \\
\hline $\operatorname{Siraha}^{\mathrm{c}}$ & Lahan & 26.73 & 86.47 & 110 & 1215 \\
\hline \multirow[t]{2}{*}{ Saptari $^{\mathrm{c}}$} & Rajbiraj & 26.54 & 86.74 & 68 & 1223 \\
\hline & Phattepur & 26.73 & 86.93 & 83 & 1212 \\
\hline Sunsari $^{\mathrm{c}}$ & Tarahara & 26.69 & 87.27 & 120 & 1320 \\
\hline
\end{tabular}

${ }^{\mathrm{a}}$ (mountain districts), ${ }^{\mathrm{b}}$ (hill districts), ${ }^{\mathrm{c}}$ (Terai districts) 
Appendix 2. The detailed results of the generalized linear mixed model effect model (GLMM) testing the effects of region, year, DTR, $T_{\text {avg }}$ and precipitation on maize, rice and wheat yield in Koshi River Basin, Nepal over the period 1987-2016. The p-values marked in bold are significant.

\begin{tabular}{|c|c|c|c|c|c|c|}
\hline \multicolumn{7}{|c|}{ Maize } \\
\hline Factors & df & Sum Sq & Mean Sq & F value & p-value & $\mathbf{R}^{2}$ \\
\hline Region & 2 & 0.46 & 0.23 & 13.82 & 0.394 & - \\
\hline Year & 29 & 14.12 & 0.49 & 29.38 & $<0.001$ & 0.784 \\
\hline Diurnal temperature range (DTR) & 1 & 0.00 & 0.00 & 0.01 & 1.000 & - \\
\hline Average temperature $\left(T_{\text {avg }}\right)$ & 1 & 0.08 & 0.08 & 5.03 & 0.046 & 0.005 \\
\hline Total precipitation & 1 & 0.01 & 0.01 & 0.80 & 0.580 & - \\
\hline Year $\times$ region & 58 & 1.17 & 0.02 & 1.22 & 0.260 & - \\
\hline Year $\times$ DTR & 29 & 0.88 & 0.03 & 1.84 & $<0.001$ & 0.049 \\
\hline Year $\times T_{\text {avg }}$ & 29 & 0.44 & 0.02 & 0.92 & 0.644 & - \\
\hline Year $\times$ precipitation & 29 & 0.84 & 0.03 & 1.74 & 0.003 & 0.046 \\
\hline \multicolumn{7}{|c|}{ Rice } \\
\hline & df & Sum Sq & Mean Sq & F value & p-value & $\mathbf{R}^{2}$ \\
\hline Region & 2 & 0.61 & 0.30 & 38.09 & 0.050 & - \\
\hline Year & 29 & 5.77 & 0.20 & 24.92 & $<0.001$ & 0.647 \\
\hline Diurnal temperature range (DTR) & 1 & 0.00 & 0.00 & 0.22 & 0.755 & - \\
\hline Average temperature $\left(T_{\text {avg }}\right)$ & 1 & 0.37 & 0.37 & 46.62 & $<0.001$ & 0.042 \\
\hline Total precipitation & 1 & 0.06 & 0.06 & 7.18 & 0.011 & 0.006 \\
\hline Year $\times$ region & 58 & 1.11 & 0.02 & 2.40 & $<0.001$ & 0.125 \\
\hline Year $\times$ DTR & 29 & 0.35 & 0.01 & 1.50 & 0.004 & 0.039 \\
\hline Year $\times T_{\text {avg }}$ & 29 & 0.28 & 0.01 & 1.22 & 0.170 & - \\
\hline Year $\times$ precipitation & 29 & 0.37 & 0.01 & 1.60 & 0.009 & 0.041 \\
\hline \multicolumn{7}{|c|}{ Wheat } \\
\hline & df & Sum Sq & Mean Sq & F value & p-value & $\mathbf{R}^{2}$ \\
\hline Region & 2 & 0.461 & 0.230 & 28.528 & 0.157 & - \\
\hline Year & 29 & 20.165 & 0.695 & 86.113 & $<0.001$ & 0.862 \\
\hline Diurnal temperature range (DTR) & 1 & 0.073 & 0.073 & 9.076 & 0.028 & 0.003 \\
\hline Average temperature $\left(T_{\text {avg }}\right)$ & 1 & 0.014 & 0.014 & 1.768 & 0.423 & - \\
\hline Total precipitation & 1 & 0.005 & 0.005 & 0.621 & 0.545 & - \\
\hline Year $\times$ region & 58 & 1.359 & 0.023 & 2.902 & $<0.001$ & 0.058 \\
\hline Year $\times$ DTR & 29 & 0.458 & 0.016 & 1.958 & $<0.001$ & 0.020 \\
\hline Year $\times T_{\text {avg }}$ & 29 & 0.522 & 0.018 & 2.229 & $<0.001$ & 0.022 \\
\hline Year $\times$ precipitation & 29 & 0.326 & 0.011 & 1.391 & 0.039 & 0.014 \\
\hline
\end{tabular}

